\title{
Iconoclasia. Historia y psicología de la violencia contra las imágenes
}

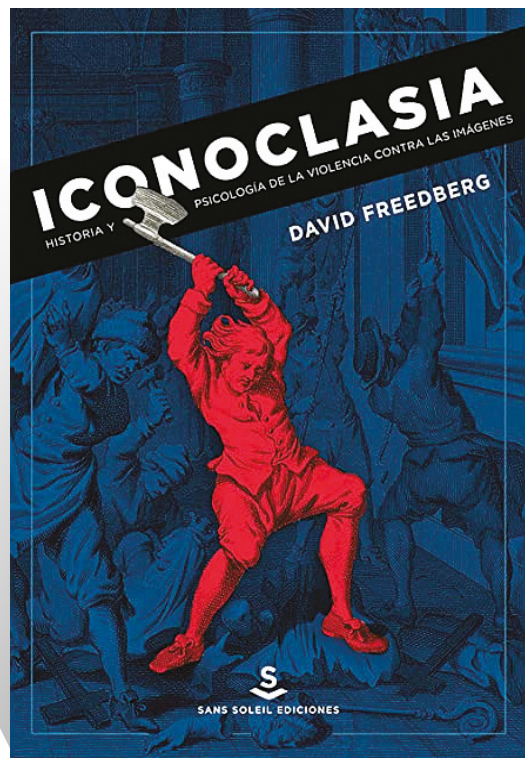

DAVID Freedberg. Iconoclasia. Historia y psicología de la violencia contra las imágenes, Marina Gutiérrez de Angelis (trad.) Vitoria-Gasteiz-Buenos Aires: Sans Soleil, 2017, ISBN: 978-84-947354-3-1, $272 \mathrm{pp}$.

\section{Elena Muñoz Gómez I Universidad de Salamanca}

En 2017 Sans Soleil publicó su homenaje a David Freedberg, una “autorevisión" compuesta de ensayos inéditos en castellano, donde el historiador aborda el fenómeno de la iconoclasia en el cruce de historia del arte, psicología, sociología, política, antropología y neurociencia. Aunque la imagen -en palabras del profesor sudafricano- incita al impulso "amoroso" de protegerla como "proyección en las representaciones del mundo", el movimiento puede invertirse. Tal como se plantea, la destrucción de imágenes se basa, como el arte, en la relación de los cuerpos representados y los cuerpos espectadores. Por tanto la iconoclasia es objeto de estudio de la historia del arte materialista. Pero el investigador ilustra con su biografía la dificultad de enfrentarse a la destrucción como tema contrario al 'espíritu' que aboga por la conservación de las imágenes artísticas. 
El Prefacio introduce al libro con una revisión historiográfica de tono autobiográfico. Cuando Freedberg empezó su investigación en los años 60, el fenómeno había sido atendido desde una perspectiva política centrada en la encarnación, entendido el dogma como manifestación del deseo de ver las imágenes como sustitutas del mundo. Se valoran los estudios de iconoclasia bizantina, judía, islámica, grecorromana, del puritanismo británico o la Reforma, que sentaron las bases para la publicación de El poder de las imágenes en 1989, descrito como resultado de un análisis de las "respuestas emocionales y viscerales a las imágenes y al arte", y de una "evaluación crítica de los episodios históricos y contemporáneos de la iconoclasia y sus motivaciones". El siguiente hito se marca en la Caída del Muro y la sustitución de regímenes y sus símbolos, al tiempo que aumentan ataques a un arte que se abre a nuevas formas comerciales. La recopilación bibliográfica continua con el revisionismo de los años 90, los estudios sobre Oriente y África, y la antropología que alimentan las visiones históricopsicológicas del siglo XXI. El último jalón, la guerra de Irak, por fin evidencia la dificultad de controlar las imágenes a una "nueva ola" de investigaciones.

En el primer capítulo, Iconoclasia, original de la edición, se recopilan cuestiones centrales del estudio: censura, encarnación, género, reproducción, destrucción creativa, implicaciones históricas, teológicas, políticas y psicológicas de estas facetas de la iconoclasia, y sus motivaciones y pretextos.

Se parte de la revuelta protestante de $1566^{1}$. Los factores que conducen a la iconoclasia ligada a este evento político y religioso se esquematizan en los binomios idolatría-figuración y encarnación-carnalidad de la imagen, desenterrando las raíces cristianas de los argumentos reformistas, desde la moderación de Erasmo al extremo de Calvino (irrepresentabilidad de lo inmaterial, concupiscencia de la materialidad y obstrucción de la imagen a la devoción que debe rendirse al prototipo). Al detallar los medios de difusión de estas teorías, los sucesos iconoclastas se relacionan con los sermones: bajo pretexto del abuso católico a las imágenes, cuando se trata de independizar Países Bajos del gobierno español, los predicadores alientan a la "purificación" de las iglesias para adecuarlas al culto protestante. Se trata también la postura contraria, la manera en que, en el Concilio de Trento, se unifican los argumentos católicos reafirmando también principios medievales (encarnación, transferencia al prototipo de la devoción al signo, y legitimidad del culto gregoriano) con los que se defiende una imagen didáctica, moralizante y memorativa. El lazo del arte y la acción social se hace patente en un análisis de monumentos y obras de reproducción implicadas en el debate teórico y en los acontecimientos políticos, dando como resultado una sutil relación dialéctica entre Catolicismo y Reforma. El campo de estudio es rico en matices y paradojas. Los efectos de este breve periodo iconoclasta, según Freedberg, fueron permanentes, y positivos a corto plazo: pese al haber erradicado la figuración en las iglesias, el protestantismo abrió una posibilidad de innovación artística inexplorada hasta entonces.

1. Se estudia en el capítulo 2, Arte e iconoclasia. 1525-1580: El caso de los Países Bajos del Norte, ensayo para la exposición de 1986, Kunst voor de Beeldenstorm. Noordnederlandse Kunst 1525-1580 en el Rijksmuseum. 
El historiador define la iconoclasia en la Reforma como expresión social de ruptura con el poder político y religioso bajo pretexto teológico, pero este no es el único contexto. En la iconoclasia ideológica de la Revolución Francesa, el argumento teológico es secundario. Entonces se destruyen y musealizan imágenes del antiguo régimen; conservarlas -según el autor- es usurpar el pasado, y destruirlas conlleva dejar huella visual del acto. Al derribo fotografiado de la estatua de Napoleón siguen las de líderes rusos, la persecución y musealización nazi, ataques a efigies de Saddam Hussein y retratos en la Primavera Árabe que suman el factor de la tendencia no-figurativa islámica y enfatizan la creencia en la vida de la imagen que subrayan recientes episodios africanos. De esta diversidad contextual de la iconoclasia se extrae una clasificación de estereotipos, "motivos de la destrucción" que ejemplifican los grabados de Heemskerck: orinar en estatuas, derribarlas con cuerdas, dañar sus ojos, boca, rostros... El método reduccionista a cambio evidencia similitudes persistentes de formas de acción sujetas -según Freedberg- a condiciones biológicas y a la difusión artística de formas evocadoras de emoción, que dan pie a implicaciones psicológicas: el ataque al cuerpo representado se percibe sobre el propio -apunta el historiador- y esta "empatía" hace efectivo el daño iconoclasta. Se reconoce que el fenómeno no se cierra en categorías ni se explica sólo como fusión de factores históricos, teológicos, políticos, biológicos o psicológicos, en relación con la persona o idea representada y la creencia en la vida de la imagen; si bien la encarnación, ese dogma ligado a la ilusión de fusión de imagen y prototipo vivo, es central en el estudio.

Con el análisis de la censura -antesala de la iconoclasia donde se pretende anular la legitimidad de una persona o idea- se descubre el engranaje de sentimientos opuestos: el deseo por el cuerpo representado o la imagen del cuerpo se percibe peligroso y es contestado con un odio que puede diagnosticarse patológico o monopolizarse. Ese deseo de control del poder de las imágenes se relaciona con la ansiedad que produce su sensualidad y aumenta con su reproducción a la par que se multiplican también los ataques a lo que representan y a esas respuestas mismas. Así Freedberg explica cómo en la historia de las religiones, la censura administra la información y de paso evidencia el miedo al cuerpo en la imagen.

La encarnación también se señala como motor de iconoclasia de guerra, o paz capitalista, en contextos que promueven destrucciones poco selectivas o estratégicas a gran escala, expolios con los que se trata de anular la legitimidad de una cultura, borrar historia y lucrarse. Ello contrasta con una iconoclasia individual, aislada, no organizada ni debida a opinión pública, que no muestra síntomas de comportamiento normal, pero indica lo normalizado del deseo, de la ilusión de vida en la imagen y la respuesta de odio que trata de romperla. La dialéctica de estos actos individuales y colectivos es, para Freedberg, el latido del asunto, y aunque los primeros no puedan categorizarse, el esquema de sus generalidades resulta revelador ${ }^{2}$ :

2. Estas motivaciones recurrentes se tratan en Los iconoclastas y sus motivos, capítulo 3 del libro, publicado en el Second Horst Gerson Memorial Lecture en la Universidad de Groningen en 1985, en relación con el proyecto Art, Humanities, and Neuroscience de la Italian Academy for Advanced Studies en Columbia, iniciado en 2001. 
Se recopilan varios casos del siglo XX. Entre ellos, los ataques a la Ronda nocturna de Rembrandt demuestran que el atacante suele percibirse como marginal, social o psicológico; el rasgado a la Venus del Espejo de Velázquez bajo pretexto feminista se descubre movido por el sentimiento radical de la ofensa moral de la imagen; el caso de la Adoración al Becerro de Poussin es ejemplo de "memoria popular" de iconografía que puede subyacer a una elección moralista; y la justificación del atacante al retrato de la Princesa de Gales en la Galería Nacional - pretendía visibilizar la causa irlandesa en Londres sin ejercer violencia a la persona- denota la posibilidad de pensar contra la anulación de la diferencia entre imagen y prototipo. Esta iconoclasia denota una búsqueda de atención, de publicidad, articulando patología, arte y dinero que entra en juego a través del énfasis sensacionalista de la prensa en el valor de la obra. Y, de nuevo, el fenómeno empieza y termina con el pensamiento simbólico: el ataque a la materialidad del signo desvela que la fusión de significante y significado que mueve el acto es ilusoria. Ni la explicación teológica ni la noción de magia acaban de dar razón de la iconoclasia. Hasta dónde importan las "pasiones primitivas", es otro interrogante que queda abierto.

La relación publicidad-dinero reaparece en el análisis del caso iconoclasta en Sudáfrica, junto a la combinación de medios de reproducción, política, género, pornografía, raza e iconofobia ${ }^{3}$. Este episodio espectacular de iconoclasia derivado de la censura -o viceversa- se narra a modo de autobiografía y aplicando la teoría de la imagen infamante de Ortalli a un estudio sociopsicológico. Freedberg fue invitado por el Instituto de Estudios Avanzados de Stellenbosch en 2012 a impartir una conferencia (Iconoclasm, Past and Present) con motivo de una exposición callejera de esculturas que suscitó que fuesen atacadas bajo pretexto de que el arte debe guardarse en el museo y que las instituciones requieren permiso ciudadano para sacarlas al espacio público. En aquel tiempo Brett Murray había pintado al presidente Jacob Zuma -hacía poco acusado de violación- con el pene desnudo y alusiones al brazo militar del partido gobernante, el CNA, que aprovechó la ofensa para reforzarse. Con el argumento de que la sátira sexual afirmaba prejuicios raciales, la obra fue convertida en instrumento ideológico, cuando las reivindicaciones de género entraban en conflicto con la política del país. Mientras Freedberg daba la conferencia, el retrato fue atacado. La justificación esta vez era que dañar el símbolo ofensivo es defender a la persona, y que la pornografía no es arte. La censura que desató el caso, para el historiador, denota reconocimiento del poder de una obra que aumenta con su carácter derivado y reproducible.

Llevando el estudio a los medios digitales se reinterpreta la pérdida del aura benjaminiana, la atenuación del poder de las imágenes debido a una reproducción que conduce a su fetichización. La guerra de Irak y el nacimiento de los selfies con las fotos de las torturas de Abu Ghraib desata un consumo visual frenético, transmisión y producción instantáneas con "prótesis oculares", “extensiones del aparato corporal", como el teléfono móvil, que provocan

3. En el capítulo 4, De la difamación a la mutilación: razón de estado y políticas de género en Sudáfrica, publicado en inglés en Images of Shame: Infamy, Defamation and the Ethics of oeconomia en 2016 con versión anterior en la revista Art South Africa en 2012. 
ansiedad por el control de imágenes con una "nueva forma de aura". La virtualidad sigue implicando corporalidad y creencia en el poder de imágenes imborrables en tanto reproducibles. Freedberg parte de Settis para comparar estos fenómenos con la damnatio memoiae que requería conservar las huellas visuales de una destrucción que, además, puede convertirse en nuevo objeto de censura: Las fotografías públicas del derribo de la estatua de Saddam en Bagdad ocultan los encuadres originales, donde aparecen los marines estadounidenses supervisando el acto; el propio historiador, engañado por estas publicaciones, denuncia la "falta de credibilidad" de las imágenes, y su autocrítica nos sugiere los riesgos de caer también en la credibilidad de la historiografía.

Otra de las cuestiones que sobresalen en el libro es la pregunta acerca del surgimiento contemporáneo de una "estética de la destrucción". El ejemplo, de nuevo, es el caso sudafricano que partía de la musealización callejera de Stellenbosch implicando el debate sobre cuál es el lugar del arte y quién tiene derecho a decidirlo. ¿Hay algún criterio incontestable que determine que una obra sea o no sea arte? Freedberg reconoce que no escapó al conato de "filisteísmo" al pensar -dice- que la destrucción no puede ser creativa, y así hace un repaso por la obra de artistas que, desde los años 50, han empleado gestos de destrucción como manera de creación en una especie de inversión de los efectos iconoclastas. A veces esto ni siquiera depende del artista, sino de la institucionalización de la obra o el equivalente de su interés ideológico y mercantil. El valor económico o social de una obra suele aumentar al ser objeto de iconoclasia, y el mismo acto de dañarla puede rentabilizarse como "extensión creativa".

Ante estas observaciones cabe preguntarse si el fenómeno contemporáneo puede seguir llamándose iconoclasia, o acaso la iconoclasia desde el principio no debiera definirse como destrucción, pues dichos gestos 'destructivos' del arte conceptual anulan la negación -la acción de la destrucción- convirtiéndola en faceta positiva de la creación. En este sentido la investigación de Freedberg se adentra en el meollo del asunto, aun reconociendo que el pensar que los gestos creativos y destructivos son la misma cara de la moneda, es la moda. Si la iconoclastia y la idea de creación de imágenes han estado siempre ligadas -recordemos la huella visual que requiere dejar constancia de un acto iconoclasta para asegurar su función ideológica o religiosa- , podemos dudar también de la posibilidad de aislar y definir el fenómeno como pura destrucción de imágenes. Si la testificación del gesto material de la destrucción iconoclasta es necesaria para su efectividad, ¿qué es la iconoclasia, sino un modo de hacer imágenes de otras imágenes? En cualquier caso, el tema nos "devuelve" a la función de lo manual y material, dice el autor, en un momento en que la reflexión artística debe esforzarse para no ser llevada por una idea de progreso que blande lo virtual y conceptual. La teoría de la respuesta permite abordar la corporalidad de los gestos conceptuales, y por eso -dice Freedberg- es importante pensar la iconoclasia desde la historia del arte: ¿qué papel tiene el arte en la vida?

El último capítulo del libro, Haciendo y destruyendo imágenes. La iconoclasia en la era de la reproducción digital, también original del volumen, deja abiertos los problemas de la relación de las imágenes y las personas al abordar la situación actual de la cultura a partir de las producciones visuales del ISIS: grupos iconoclastas que necesitan imágenes y las destruyen demostrándose que tienen vida -asevera el historiador- a la vez que redu- 
cen a las personas a condición de imágenes que destruyen del mismo modo. El elocuente paralelismo del gatillo y el botón de la cámara no es menos inquietante que el maridaje de iconoclasia y asesinato que detecta Freedberg en una cultura donde representación y realidad se confunden; defiende que el cuerpo sigue implicado en la iconoclasia a pesar de la "creencia" de que las obras, conceptuales o digitalizadas, son inertes, al tratarse de reacciones a una percepción de realidad -nos aclara-, y la imagen, como ha argumentado la antropología, toma forma en nuestro cuerpo, en nuestra mente. El proyecto del historiador profundiza en el asunto desde la neurociencia.

Podemos comprender y hasta compartir el rechazo a imágenes de líderes -nos dice el profesor Freedberg- al lucro y dispendio en el arte, incluso a su simplicidad; pero en tanto practicantes de una ciencia que históricamente aboga por la conservación de lo bello y el testimonio del pasado, ante la destrucción de las obras -continúa- hay que vencer a la "subjetividad". Aún sin imágenes materiales conservadas, el análisis de respuestas iconoclastas obliga a considerar factores políticos, económicos, religiosos; la labor requiere de un gran bagaje y capacidad de profundización sociosicológica. El método y objeto de estudio pueden parecer inadecuados a quienes abogan por la conservación y los "sentimientos nobles" que despierta el arte. Pero la propia metodología transversal se pone a prueba en el libro: no está libre de la necesidad clasificadora de la investigación de casos concretos en la cuerda floja del reduccionismo. "Uno no puede comprender las particularidades de los fenómenos y el contexto a menos que se formulen primero y se reconozcan los aspectos comunes subyacentes -o aparentemente latentes en ellos- a fin de evaluar hasta qué punto son susceptibles de modificación por las especificidades del contexto". En conclusión, diremos que con esta obra se apunta al corazón de la idea de arte, a la relación entre la obra y su audiencia teniendo en cuenta factores históricos y biológicos, y lo que es más crucial para filósofos e historiadores: cuestiona la legitimidad de la autoridad del juicio que establece qué es y cómo debe reaccionarse ante el arte. 